NBER WORKING PAPER SERIES

\title{
REAL BUSINESS CYCLES: A NEW KEYNESIAN PERSPECTIVE
}

N. Gregory Mankiw

Working Paper No. 2882

\author{
NATIONAL BUREAU OF ECONOMIC RESEARCH \\ 1050 Massachusetts Avenue \\ Cambridge, MA 02138 \\ March 1989
}

Professor of Economics, Harvard University, and Research Associate, National Bureau of Economic Research. This paper was prepared for the Journal of Economic Perspectives. I am grateful to Laurence Ball, Susanto Basu, Marianne Baxter, Mark Bils, Lawrence Katz, Deborah Mankiw, David Romer, Joseph Stiglitz, Lawrence Summers, Timothy Taylor, David Weil, and Michael Woodford, for helpful discussions and comments, and to the National Science Foundation for financial support. This paper is part of NBER's research programs in Economic Fluctuations and in Financial Markets and Monetary Economics. Any opinions expressed are those of the author not those of the National Bureau of Economic Research. 
NBER Working Paper \#2882

March 1989

REAL BUSINESS CYCLES: A NEW KEYNESIAN PERSPECTIVE

\begin{abstract}
This paper is a critique of the latest new classical theory of economic fluctuations. According to this theory, the business cycle is the natural and efficient response of the economy to exogenous changes in the available production technology. This paper discusses several versions of this theory and argues that this line of research is unlikely to yield an empirically plausible explanation of observed economic fluctuations.
\end{abstract}

N. Gregory Mankiw National Bureau of Economic Research 1050 Massachusetts Avenue Cambridge, MA 02138 
The debate over the source and propagation of economic fluctuations rages as fiercely today as it did fifty years ago in the aftermath of Keynes's The General Theory and in the midst of the Great Depression. Today, as then, there are two schools of thought. The classical school emphasizes the optimization of private economic actors, the adjustment of relative prices to equate supply and demand, and the efficiency of unfettered markets. The Keynesian school believes that understanding economic fluctuations requires not just studying the intricacies of general equilibrium, but also appreciating the possibility of market failure on a grand scale.

Real business cycle theory is the latest incarnation of the classical view of economic fluctuations. It assumes that there are large random fluctuations in the rate of technological change. In response to these fluctuations, individuals rationally alter their levels of labor supply and consumption. The business cycle is, according to this theory, the natural and efficient response of the economy to changes in the available production technology.

My goal in this essay is to appraise this newly revived approach to the business cycle. I should admit in advance that I am not an advocate. In my view, real business cycle theory does not provide an empirically plausible explanation of economic fluctuations. Both its reliance on large technological 
disturbances as the primary source of economic fluctuations and its reliance on the intertemporal substitution of leisure to explain changes in employment are fundamental weaknesses.

Moreover, to the extent that it trivializes the social cost of observed fluctuations, real business cycle theory is potentially dangerous. The danger is that those who advise policy-makers might attempt to use it to evaluate the effects of alternative macroeconomic policies or to conclude that macroeconomic policies are unnecessary.

\section{Walrasian Equilibrium and The Classical Dichotomy}

The typical undergraduate course in microeconomics begins with partial equilibrium analysis of individual markets. A market for a good is characterized by a downward sloping demand curve and an upward sloping supply curve. The price of the good is assumed to adjust until the quantity supplied equals the quantity demanded.

The course then builds up to Walrasian general equilibrium. In this walrasian equilibrium, prices adjust to equate supply and demand in every market simultaneously. The general equilibrium system determines the quantities of all goods and services sold and their relative prices. The most important theoretical result, after the existence of such a Walrasian equilibrium, is the "invisible hand" theorem: the equilibrium is Pareto efficient.

Courses in microeconomics thus show how employment. 
production, and relative prices are determined without any mention of the existence of money, the medium of exchange. The simplest way to append money to the model is to specify a money demand function and an exogenous moriey supply. Money demand depends on the level of output and the price level. The level of output is already determined in the Walrasian system. The price level, however, can adjust to equate supply and demand in the money market.

Introducing money in this way leads to the classical dichotomy. (Patinkin 1956) Real variables, such as employment, output, and relative prices, including the real interest rate, are determined by the Walrasian system. Nominal variables, such as the price level, the nominal wage, and the nominal interest rate, are then determined by the equilibrium in the money market. of course, since nominal variables do not affect real variables, the money market is not very important. This classical view of the economy suggests that, for most policy discussions, the money market can be ignored.

The professor of macroeconomics must in some way deal with the classical dichotomy. Given the assumptions of Walrasian equilibrium, money is largely irrelevant. The macroeconomist must either destroy this classical dichotomy or learn to live with it.

Keynesian macroeconomics destroys the classical dichotomy by abandoning the assumption that wages and prices adjust instantly to clear markets. This approach is motivated by the observation 
that many nominal wages are fixed by long-term labor contracts and many product prices remain unchanged for long periods of time. Once the inflexibility of wages and prices is admitted into a macroeconomic model, the classical dichotomy and the irrelevance of money quickly disappear.

Much of the early work in the new classical revolution of the 1970 s attempted to destroy the classical dichotomy without abandoning the fundamental axiom of continuous market clearing. (Lucas 1972,1973) These models were based on the assumption that individuals have imperfect information regarding prices. These individuals therefore confuse movements in the overall price level (which under the classical dichotomy should not matter) with movements in relative prices (which should matter). An unanticipated decrease in the money supply leads individuals to infer that the relative prices of the goods they produce are temporarily low, which induces them to reduce the quantity supplied. While the fascination with this sort of story was substantial in the 1970s, it has attracted relatively few adherents in the $1980 \mathrm{~s}$. It is hard to believe that confusion about the price level is sufficiently great to generate the large changes in quantities observed over the business cycle.

In contrast to both the Keynesian and the early new classical approaches to the business cycle, real business cycle theory embraces the classical dichotomy. It accepts the complete irrelevance of monetary policy, thereby denying a tenet accepted by almost all macroeconomists a decade ago. Nominal variables, 
such as the money supply and the price level, are assumed to have no role in explaining fluctuations in real variables, such as output and employment.

Real business cycle theory thus pushes the Walrasian model farther than it has been pushed before. In evaluating whether it provides a successful explanation of recessions and booms, two questions naturally arise. First, why are there such large fluctuations in output and employment? And second, why do movements in nominal variables, such as the money supply, appear related to movements in real variables, such as output?

\section{Classical and Keynesian Views of Economic Fluctuations}

The only forces that can cause economic fluctuations, according to real business cycle theory, are those forces that change the walrasian equilibrium. The Walrasian equilibrium is simply the set of quantities and relative prices that simultaneously equate supply and demand in all markets in the economy. To understand how real business cycle theory explains the business cycle, it is necessary to look into the fundamental forces that change the supplies and demands for various goods and services.

Many sorts of macroeconomic disturbances can in principle generate fluctuations in real business cycle models. For example, changes in the level of government purchases or in the investment tax credit alter the demand for goods and therefore affect the Walrasian equilibrium. Changes in the relative price 
of oil alter the equilibrium allocation of labor among alternative uses. Many of the macroeconomic disturbances that receive much attention among keynesian macroeconomists will also have important effects in real business cycle models. There is, however, substantial disagreement between the two schools regarding the mechanisms through which these disturbances work. Consider the case of a temporary increase in government purchases. Almost all macroeconomists agree that such a change causes an increase in output and employment, and the evidence. mainly from wartime experience, supports this prediction. Yet the explanations of this effect of government purchases differ greatly. (CE. Barro 1987 and Dornbusch and Fischer 1987)

Real business cycle theory emphasizes the intertemporal substitution of goods and leisure. It begins by pointing out that an increase in government purchases increases the demand for goods. To achieve equilibrium in the goods market, the real interest rate must rise, which reduces consumption and investment. The increase in the real interest rate also causes individuals to reallocate leisure across time. In particular, at a higher real interest rate, working today becomes relatively more attractive than working in the future; today's labor supply therefore increases. This increase in labor supply causes equilibrium employment and output to rise.

While Keynesian theory also predicts an increase in the real interest rate in response to a temporary increase in government purchases, the effect of the real interest rate on labor supply 
does not play a crucial role. Instead, the increase in employment and output is due to a reduction in the amount of labor unemployed or underutilized. In most keynesian theory, the labor market is characterized as often in a state of excess supply. In contrast, the Walrasian approach of real business cycle theory does not allow for the possibility of involuntary unemployment.

Both real business cycle theory and Keynesian theory thus conclude that increases in government purchases increase output and employment. This example shows that some of the prominent implications of Keynesian models also come out of intertemporal Walrasian models. Macroeconomists face a problem of approximate observational equivalence: many observed phenomena are consistent with both the classical and Keynesian paradigms.

\section{The Central Role of Technological Disturbances}

While many sorts of macroeconomic disturbances can in principle cause economic fluctuations in real business cycle models, most attention has focused on technological disturbances. The reason is that other sorts of disturbances are unlikely to generate fluctuations in real business cycle models that resemble actual economic fluctuations.

An obvious but important fact is that over the typical business cycle, consumption and leisure move in opposite directions. When the economy goes into a recession, consumption falls and leisure rises. When the economy goes into a boom, 
consumption rises and leisure falls. Explaining this phenomenon is potentially problematic for real business cycle theory: consumpiion and leisure would often be expected to move together. since both are normal goods. In the example of a temporary increase in government purchases, both consumption and leisure should fall. Many other changes in the demand for goods, such as a change due to a temporary investment tax credit, also should cause consumption and leisure to move together.

Real business cycle theory must explain why individuals in a recession find it rational to increase the quantity of leisure they demand at the same time they decrease the quantity of goods they demand. The answer must be that the price of leisure relative to goods, the real wage, falls in a recession. Hence, a crucial implication of real business cycle theory is that the real wage is procyclical.

If the production function were unchanging and demand shocks were the source of fluctuations, real business cycle theory would have trouble generating a procyclical real wage. Since labor input is low in a recession, one would expect that the marginal product of labor and thus the real wage should be high. With an unchanging production function, diminishing marginal returns to labor would produce a countercyclical real wage, not the procyclical real wage necessary to explain the fluctuations in

IAlternatively, one could explain the observed pattern without a procyclical real wage by positing that tastes for consumption relative to leisure vary over time. Recessions are then periods of "chronic laziness." As far as I know, no one has seriously proposed this explanation of the business cycle. 
consumption and leisure.

Real business cycle theorists therefore assume that there are substantial fluctuations in the rate of technological change. In a recession, the available production technology is relatively unfavorable. The marginal product of labor and thus the real wage are low. In response to the low return to working, individuals reduce consumption and increase leisure.

Since real business cycle theory describes economic fluctuations as a changing Walrasian equilibrium, it implies that these fluctuations are efficient. Given the tastes of individuals and the technological possibilities facing society, the levels of employment, output, and consumption cannot be improved. Attempts by. the government to alter the allocations of the private market, such as policies to stabilize employment, at best are ineffective and at worst can do harm by impeding the "invisible hand."

of all the implications of real business cycle theory, the optimality of economic fluctuations is perhaps the most shocking. It seems undeniable that the level of welfare is lower in a recession than in the boom that preceded it. Keynesian theory explains the reduction in welfare by a failure in economic coordination: because wages and prices do not adjust instantaneously to equate supply and demand in all markets, some gains from trade go unrealized in a recession. In contrast, real business cycle theory allows no unrealized gains from trade. The reason welfare is lower in a recession is, according to these 
theories, that the technological capabilities of society have declined.

\section{The Evidence on Technological Disturbances}

$$
\text { Advocates of real business cycle theories have trouble }
$$

convincing skeptics that the economy is subject to such large and sudden changes in technology. It is a more standard presumption that the accumulation of knowledge and the concurrent increase in the economy's technological opportunities take place gradually over time. Yet to mimic observed fluctuations, real business cycle theorists must maintain that there are substantial shortrun fluctuations in the production function.

Edward Prescott ( 1986$)$ has offered some direct evidence on the importance of technological disturbances. He examines changes in total factor productivity for the United states economy--the percent change in output less the percent change in inputs, where the different inputs are weighted by their factor shares. This "solow residual" should measure the rate of technological progress. Prescott points out that there are substantial fluctuations in the solow residual, a finding which suggests a potentially important role for technological disturbances as a source of business cycle fluctuations.

Figure 1 presents my calculation of the solow residual and the percent change in output yearly since 1948. (Both variables are for the private economy less agriculture and housing services.) Like Prescott, I find substantial fluctuations in 
measured total factor productivity. For example, in 1982 total factor productivity fell by 3.5 percent, while in 1984 it rose by 3.4 percent. One might interpret these numbers as showing that the economy's ability to convert inputs into outputs--the aggregate production function--varies substantially from year to year.

Figure 1 also shows that measured productivity is highly cyclical. In every year in which output fell, total factor productivity also fell. If the Solow residual is a valid measure of the change in the available production technology, then recessions are periods of technological regress.

The solow residual need not be interpreted as evidence regarding exogenous technological disturbances, however. The standard explanation of cyclical productivity is that it reflects labor hoarding and other "off the production function" behavior. Productivity appears to fall in a recession because firms keep unnecessary and underutilized labor. In a boom the hoarded laborers begin to put out greater effort; output increases without a large increase in measured labor input. 2

An examination of the data from the early 1940 s appears to support this standard explanation of the cyclical behavior of

2

A related explanation of the procyclical behavior of the Solow residual has recently been proposed by Hall (1987): Hall points out that if price exceeds marginal cost because of imperfect competition, then the measured solow residual will appear procyclical even if the true production technology is unchanging. Alternatively, the Solow residual could reflect endogenous changes in technology due to demand shocks: such endogeneity might arise if, for example, learning-by-doing is important. 
productivity. The increase in output associated with the world War II build-up is most plausibly a demand-driven phenomenon. Yet from 1939 to 1944 measured total factor productivity grew an average of 7.6 percent per year. (By contrast, the most productivity has grown in any year since then is 5.2 percent in 1950.) One might interpret this finding as showing that the economic boom of the $1940 \mathrm{~s}$ was in fact driven by supply shocks rather than demand shocks. A more appealing interpretation is that the solow residual is not a good measure over short horlzons of changes in the economy's technological abllities.

once the Solow residual is rejected as a measure of year-toyear changes in the available production technology, there is no longer any direct evidence for substantial technological disturbances. Yet to generate fluctuations that mimlc observed fluctuations, real business cycle models require such disturbances. The existence of large fluctuations in the available technology is a crucial but unjustified assumpion of real business cycle theory.

An advocate of real business cycle theory might respond that economic models often rely on assumptions for which there ts no formal evidence. Yet more casual evidence also does not give plausibility to the assumption of substantial technological disturbances. Recessions are important events; they receive widespread attention from pollcy-makers and the media. There is, however, no discussion of declines in the available technology. If society suffered some important adverse technological shock, 


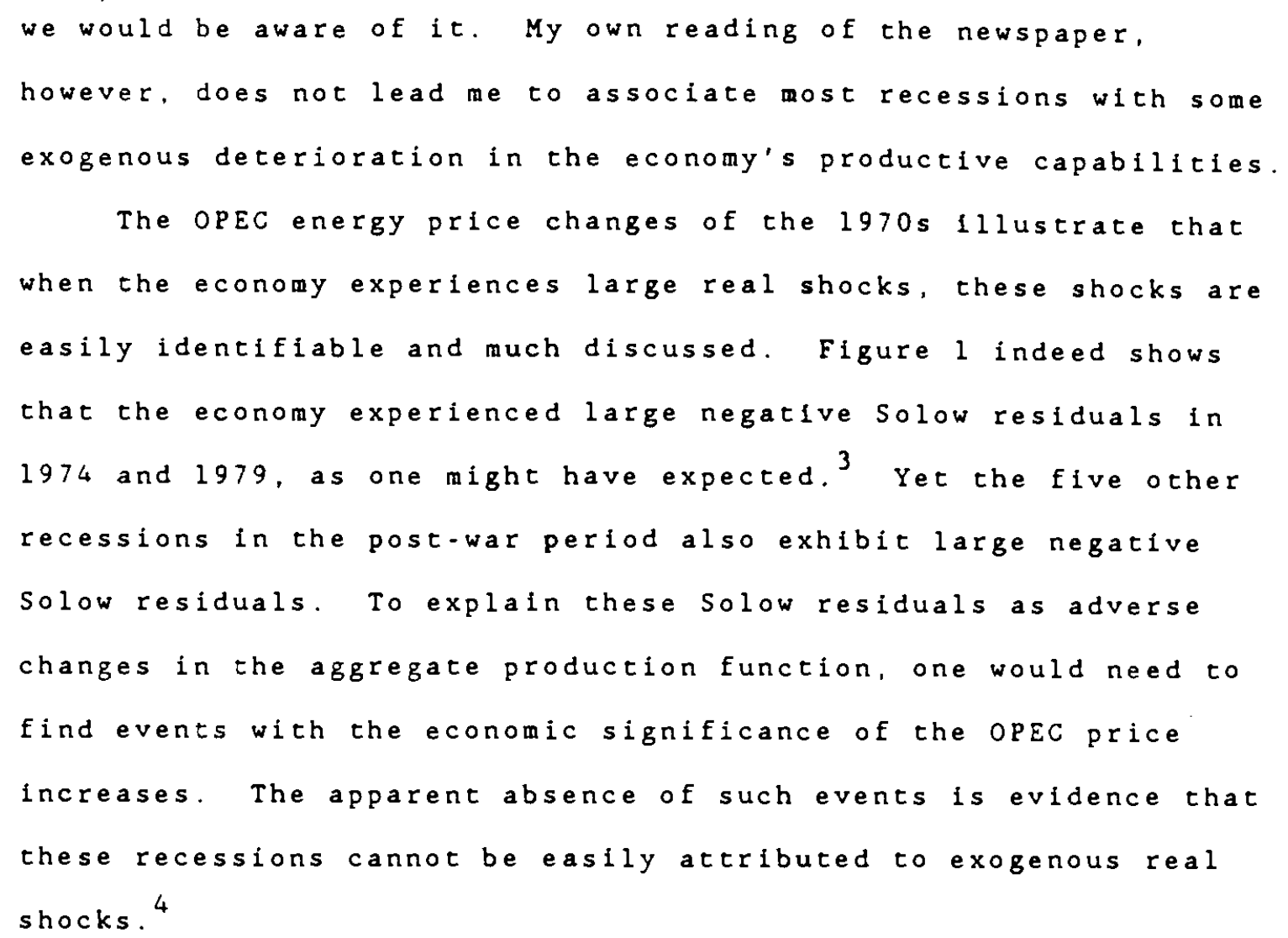

\section{Labor Supply and Intertemporal substitution}

Real business cycle theorists assume that fluctuations in employment are fully voluntary. In other words, they assume the economy always finds itself on the labor supply curve. Yet over the typical business cycle, employment varies substantially while

3 Whether changes in energy prices affect the solow residual computed from GNP depends on a variety of issues involving the construction of index numbers like GNP. See Bruno and Sachs (1985, p. 43) for a discussion.

${ }^{4}$ Hamilton (1983) finds ofl price changes are also associated with the pre-OPEC recessions. Yet these prices changes are much too small to explain plausibly such large declines in productivity. . 
the determinants of labor supply--the real wage and the real interest rate--vary only slightly. To mimic this observed pattern, real business cycle models require that individuals be very willing to reallocate leisure over time. Individuals must significantly reduce the quantity of labor they supply in response to small temporary reductions in the real wage or in response to small decreases in the real interest rate.

It is unlikely, however, that individuals are so responsive to intertemporal relative prices. Econometric evidence on labor supply typically finds that the willingness of individuals to substitute leisure over time is slight. If leisure were highly intertemporally substitutable, as raal business cycle theorists assume, then individuals facing expected increases in their real wage should work little today and much in the future. Individuals facing expected decreases in their real wage should work hard today and enjoy leisure in the future. Yet studies of individual labor supply over time find that expected changes in the real wage lead to only small changes in hours worked.

(Altonji 1985, Ball 1985) Individuals do not respond to expected real wage changes by substantially reallocating leisure over time.

Personal experience and introspection provide another way to judge the behavioral responses on which real business cycle models rely. One key behavioral response is that quantity of labor supplied reacts substantially to the real interest rate. Without such intertemporal substitution, real business cycle 


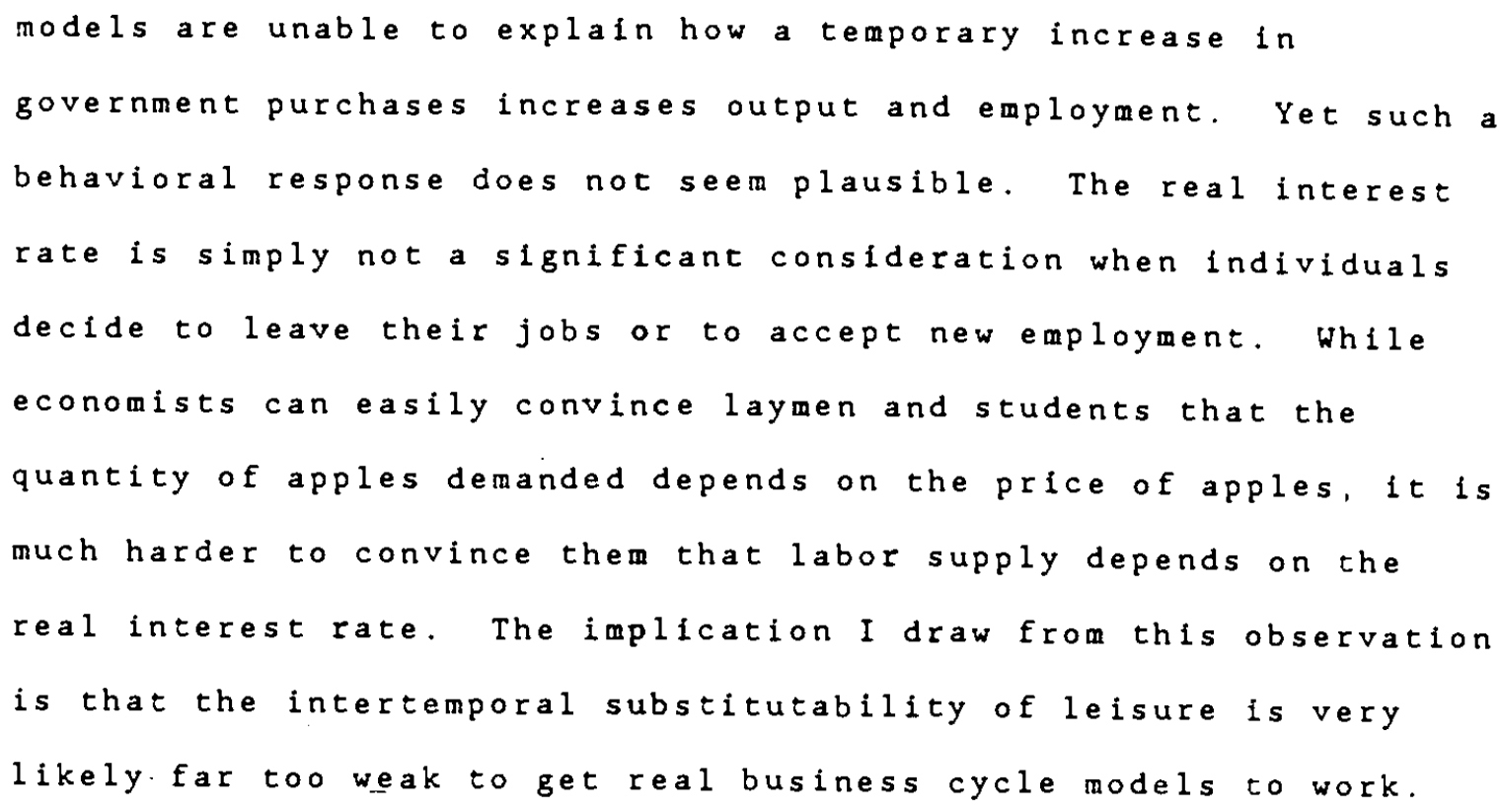

\section{Real Business Cycle Theories with Multiple Sectors}

The real business cycle theories I have been discussing so far treat production as if it takes place in a single industry. This abstraction, however, is not characteristic of all real business cycle theories.

Some real business cycle theories emphasize changes in the technologies of different sectors, rather than economy-wide changes in technology. (Long and Plosser 1983) These models highlight the interactions among the sectors. Even if the shocks to the different sectors are independent, the outputs of the different sectors move together. For example, an adverse shock to one sector reduces the wealth of the individuals in the economy; these individuals respond by reducing their demand for 
al1 goods. An observer would see an aggregate business cycle, even without a single aggregate shock.

To get these real business cycle models to work, however, the number of independent sectoral shocks cannot be too great. If there were many independent sectoral shocks and labor were moblle between sectors, then the law of large numbers would guarantee that these shocks and their effect on the aggregate economy would average out to zero. To get an aggregate business cycle, these models therefore require that there be only a few sectors and that these sectors be subject to large technological disturbances. These models are therefore similar to the singlesector theories and suffer from the same weaknesses: the absence of any direct evidence for such large technological disturbances and the implausibility of strong intertemporal substitutability of leisure.

A second type of sectoral shock theory emphasizes the costly adjustment of labor among sectors. (Lilien 1982) These models, which depart more from the Walrasian paradigm, assume that when a worker moves from one sector to another, a perlod of unemployment is required, perhaps for job search. In this case, independent shocks across many sectors do not offset each other. Recessions are, according to these theories, periods of more sectoral shocks and thus greater intersectoral adjustment.

This type of real business cycle theory may appear more plausible than those relying on substantial aggregate productivity shocks and intertemporal substitution. It is 


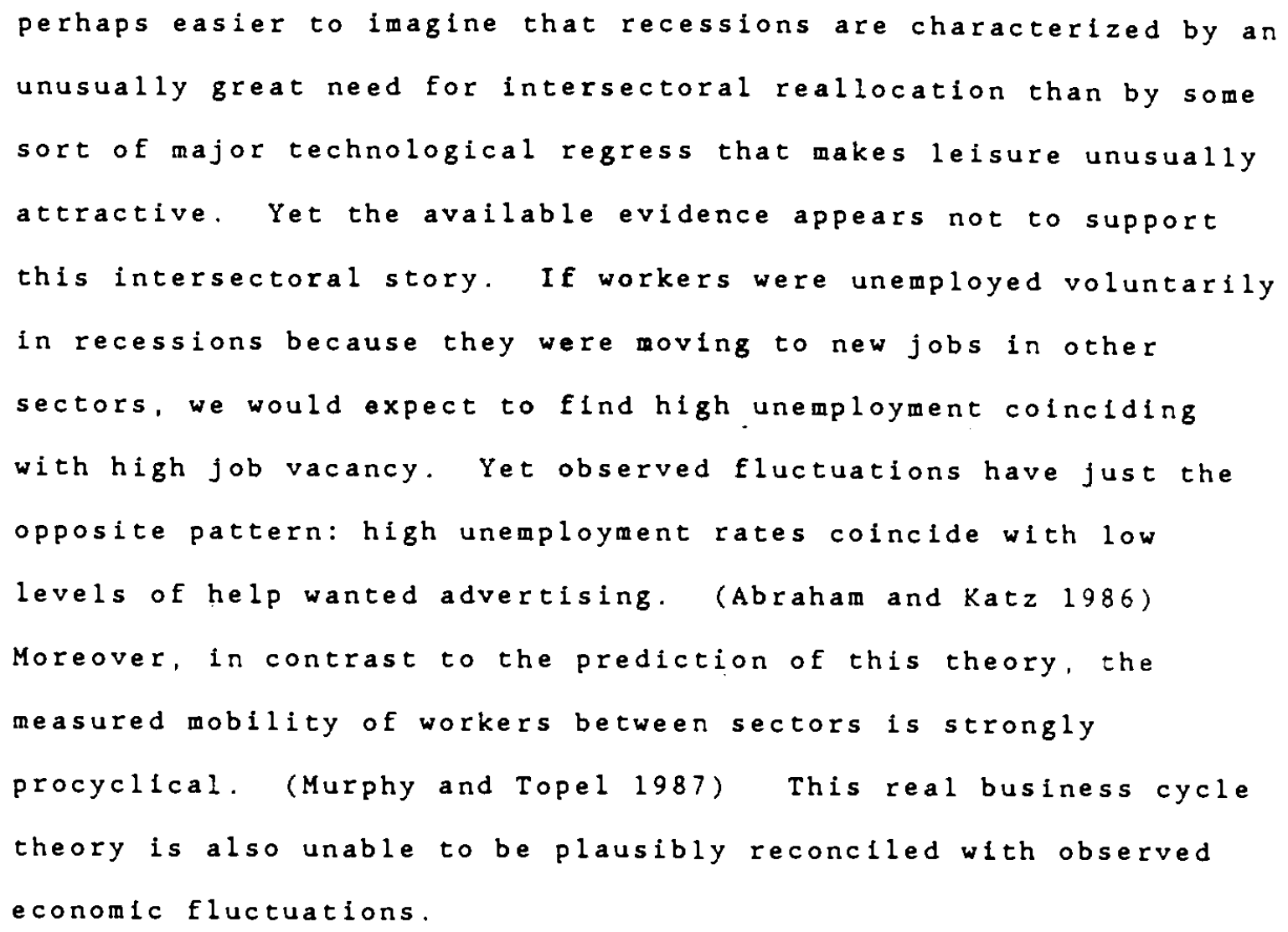

Money and Prices over the Business Cycle

Before real business cycle theory entered the macroeconomic debate in the early $1980 \mathrm{~s}$, almost all macroeconomists seemed to agree on one conclusion: money matters. Both historical discussions of business cycles (Frledman and Schwartz 1963) and more formal econometric work (Barro 1977) pointed to the Federal Reserve as an important source of macroeconomic disturbances. While there was controversy as to whether systematic monetary policy could stabilize the economy, it was universally accepted that bad monetary policy could be destabilizing. 
It is ironic that real business cycle theory arose in the wake of Paul Volcker's disinflation. Many economists view this recent experience as clear confirmation of the potency of monetary policy. Volcker announced he was going to slow the rate of money growth to achieve a lower rate of inflation; the rate of money growth in fact slowed down; and one of the deepest post-war recessions followed, as did an eventual reduction in the rate of inflation. This set of events is easy to explain within the context of keynesian theory with its emphasis on the gradual adjustment of wages and prices. It is less easy to explain within the context of real business cycle theory. 5

Robert king and Charles Plosser (1984) explain the historical association between money and output by arguing that the money supply endogenously responds to fluctuations in output. Standard measures of the money supply such as Ml are mostly inside money, that is, money created by the banking system. king and plosser suggest that the transactions services of inside money should be viewed as simply the "output" of one sector of the economy, the banking sector. Just as one should expect the outputs of different sectors to move together within a multi. sector real business cycle model, one should expect the output of the banking sector to move with the outputs of other sectors. An increase in productivity in any sector will tend to increase the

5 The recent disinflation is not unusual. Romer and Romer (1989) show that output typically falls after the Fed makes an explicit decision to reduce inflation, which they interpret as evidence against real business cycle theory. 
demand for transactions services; the banking system responds by creating more inside money. Hence, the procyclical behavior of standard monetary aggregates cannot necessarily be interpreted as evidence that changes in outside money caused by the monetary authority have real effects.

While the story of King and Plosser can explain the procyclical behavior of money, it cannot explain the procyclical behavior of prices. It is a well documented fact that, in the absence of identifiable real shocks such as the OPEC oil price changes, inflation tends to rise in booms and fall in recessions. This famous Phillips curve correlation played a central role in the macroeconomic debate of the 1960s, and it was the primary empirical motivation for the early new classical theories in the 1970s. (Friedman 1968, Lucas 1972) Yet since the model of King and Plosser generates procyclical money through the demand for transactions services, these fluctuations in money will be associated with fluctuations in real balances not with fluctuations in prices. The short-run Phillips curve has thus been left without an explanation by real business cycle theorists. 6

6 Indeed, as King and Plosser point out, their model makes the counterfactual prediction that the price level should be countercyclical: since the demand for real outside money probably rises in a boom, and it is the outside money stock that pins down the price level, equilibrium in the market for outside money requires that the price level fall in a boom. 


\section{The Tradeoff Between Internal and External Conststency}

A good theory has two characteristics: internal consistency and external consistency. An internally consistent theory is one that is parsimonious; it invokes no ad hoc or peculiar axioms. An externally consistent theory is one that fits the facts; it makes empirically refutable predictions that are not refuted. All scientists, including economists, strive for theories that are both internally and externally consistent. Yet like all optimizing agents, scientists face tradeoffs. One theory may be more "beautiful," while another may be easier to reconcile with observation.

The choice between alternativa theories of the business cycle--in particular, between real business cycle theory and new Keynesian theory--is partly a choice between internal and external consistency. Real business cycle theory extends the Walrasian paradigm, the most widely understood and taugh model in economics, and provides a unified explanation for economic growth and economic fluctuations. New Keynesian theory, in its attempt to mimic the world more accurately, relies on nominal rigidities that are observed but only little understood. Indeed, new Keynesians sometimes suggest that to understand the business cycle, it may be necessary to reject the axiom of rational. optimizing individuals, an act which for economists would be the ultimate abandonment of internal consistency.

The tension between these two goals of science will undoubtedly continue. Each school of macroeconomic thought will 


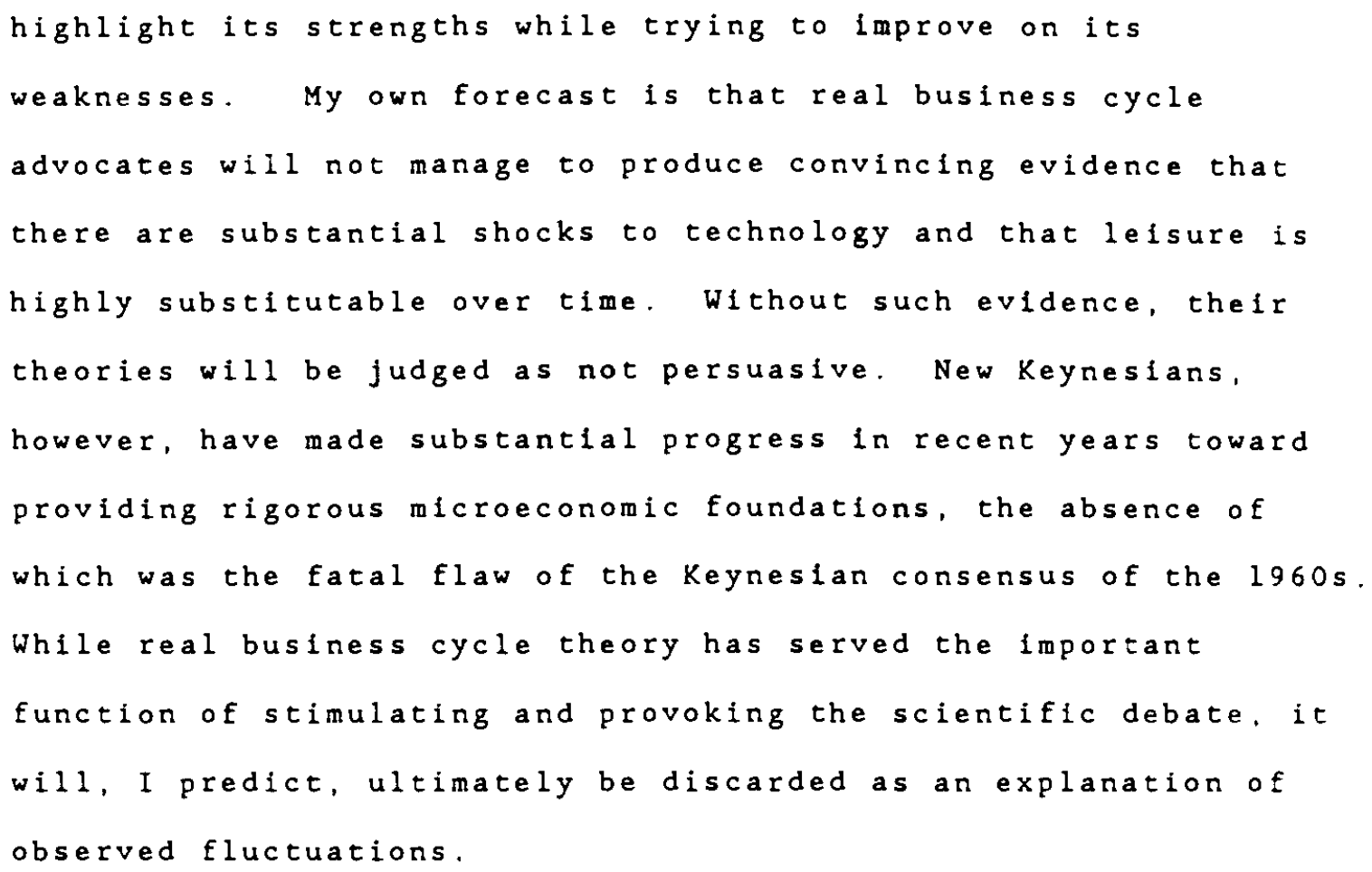




\section{References}

Abraham, Katharine G., and Lawrence F. Katz, "Cyclical

Unemployment: Sectoral Shifts or Aggregate Disturbances?"

Journal of Political Economy, June 1986, 94, 507-522.

Altonji, Joseph G., "Intertemporal Substitution in Labor

Supply: Evidence from Micro Data," Journal of Political

Economy, June 1986, Part 2, 24, S176-S215.

Bal1, Laurence, "Intertemporal Substitution and Constraints on

Labor Supply: Evidence from Panel Data," manuscript, M.I.T. 1985 .

Barro, Robert J., "Unanticipated Money Growth and Unemployment in the United States," American Economic Review, 1977, 67, 101 115 .

Barro, Robert J., Macroeconomics, New York: Wiley, 1987. Bruno, Michael, and Jeffrey Sachs, Economics of Worldwide

Stagflation, Cambridge, MA: Harvard University Press, 1985. Dornbusch, Rudiger, and Stanley Fischer, Macroeconomics, New York: McGraw-Hill, 1987.

Friedman, Milton, "The Role of Monetary Policy," American

Economic Review, $1968,58,1-17$.

Friedman, Milton, and Anna Schwartz, A Monetary History of the

United States, Princeton, NJ: Princeton University Press, 1963.

Ha11, Robert E., "Market Structure and Macroeconomic Fluctuations," Brookings Papers on Economic Activity, $1987: 1,285-322$. 
Hamilton, James D., "Oil and the Macroeconomy since World

War II," Journal of Political Economy, April 1983, 91 , $228-248$

King, Robert G., and Charles I, Plosser, "Money, Credit, and

Prices in a Real Business Cycle," American Economic Review,

June 1984, 74, $363 \cdot 380$.

Lilien, David M., "Sectoral Shifts and Cyclical Unemployment," Journal of Political Economy, August 1982, 90, 777-793.

Long, John B. Jr., and Charles I, Plosser, "Real Business

Cycles," Journal of Polttical Economy, February 1983, 91. $39-69$.

Lucas, Robert E. Jr., "Expectations and the Neutrality of Money, Journal of Economic Theory, 1972, 4, 103-124.

Lucas, Robert E. Jr., "International Evidence on Output-Inflatic Tradeoffs," Amertcan Economic Review, 1973, 63, 326-334.

Murphy, Kevin M., and Robert H. Topel, "The Evolution of

Unemployment in the United States: 1968-1985,"

NBER Macroeconomics Annual, 1987.

Patinkin, Don, Money. Interest, and Prices: An Integration of

Monetary and Value Theory, Evanston, Ill.: Row, Peterson, 1956

Prescott, Edward, "Theory Ahead of Business Cycle Measurement,"

Carnegie-Rochester Conference on Public Polfcy, Autumn 1986 ,

25, $11-44$.

Romer, Christina, and David Romer, "Does Monetary Policy

Matter: A New Test in the Spirit of Friedman and Schwartz," NBER Macroeconomics Annual; 1989, forthcoming. 
</ref_section> 


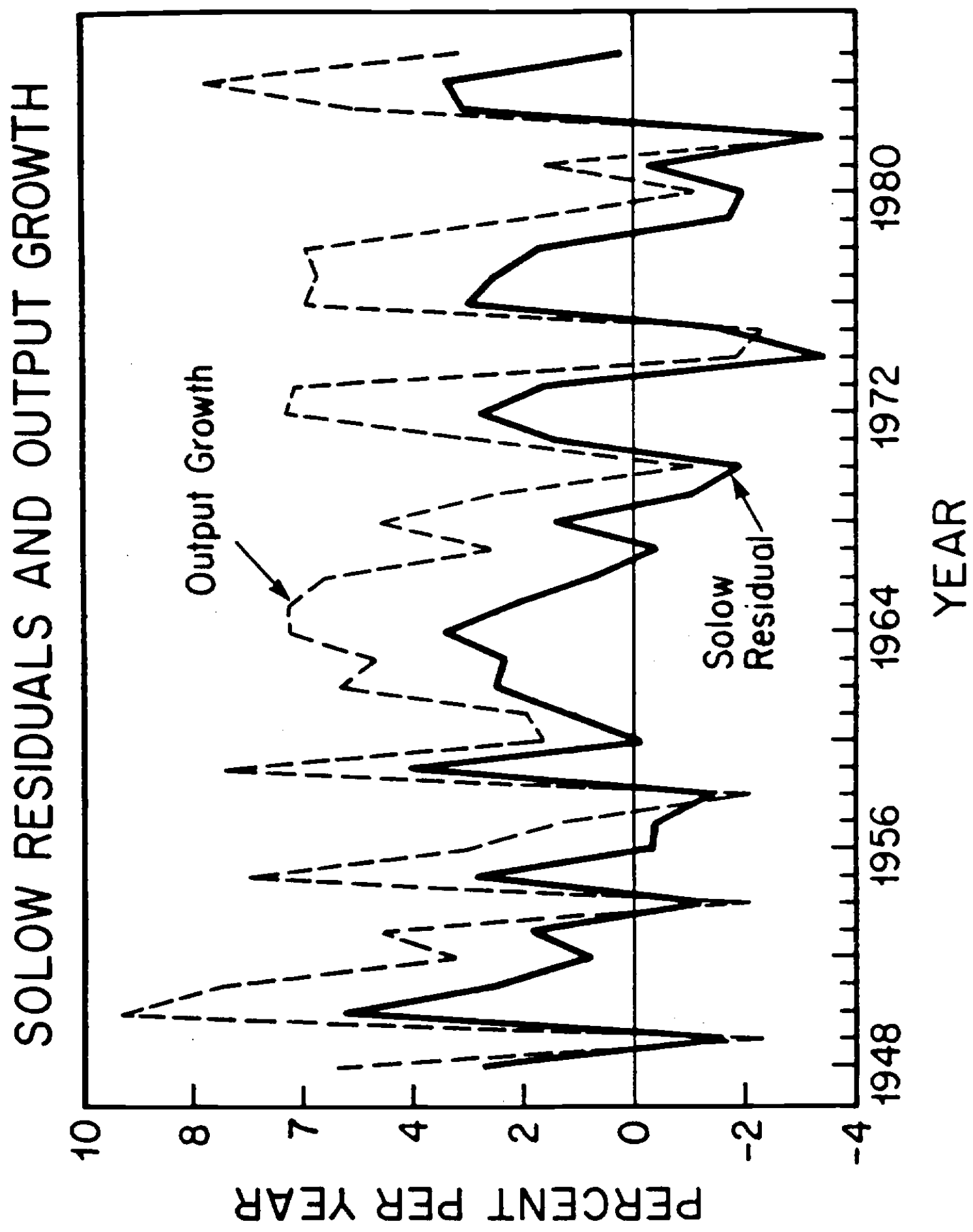

